\title{
Pemilikan Hak Atas Tanah bagi Warga Negara Asing
}

\section{Rokilah $^{1}$, Mia Mukaromah²}

Program Studi Ilmu Hukum, Universitas Serang Raya, Serang. Email: 1ilameidyfaihaazis@gmail.com, ${ }^{2}$ falsafamaitreya@gmail.com

Info Artikel:

| Diterima: 18 Desember 2018

| Disetujui: 29 Desember 2018

| Dipublikasikan: 31 Desember 2018

\begin{abstract}
This writing aims to find out how land ownership rights for Foreign Citizens as regulated in the Agrarian Basic Law (UPPA) Number 5 of 1960, in the UPPA regulate the prohibition on land ownership for Foreign Citizens. This is to reduce the existence of ownership rights to land for foreigners. Because in addition to keeping the land of Indonesian citizens not controlled by the foreigners also helping Indonesian citizens to be able to use their land to support their lives. Prohibition of land ownership rights for foreign nationals as stipulated in Article 21 of the BAL there are also exceptions to the prohibition, foreigners can use the right to use to build buildings or open a business. The method used is the empirical normative legal research method, namely the incorporation of normative legal provisions (laws) with empirical elements (legal events in society/social elements).
\end{abstract}

Keywords: Ownership, Land Rights, Foreigners.

\begin{abstract}
Abstrak
Penulisan ini bertujuan untuk mengetahui bagaimana hak kepemilikan tanah bagi Warga Negara Asing yang diatur dalam Undang-Undang Pokok Agraria (UPPA) Nomor 5 Tahun 1960, dalam UPPA mengatur mengenai larangan atas kepemilikan tanah bagi Warga Negara Asing.Hal tersebut untuk mengurangi adanya hak kepemilikan atas tanah bagi orang asing. Karena selain menjaga agar tanah WNI tidak dikuasai oleh WNA juga membantu WNI agar dapat memanfaatkan tanah hak miliknya untuk menujang kehidupannya. Larangan hak kepemilikan tanah bagi Warga Negara Asing dalam yang diatur dalam Pasal 21 UUPA terdapat pula pengecualian dalam larangan tersebut, orang asing dapat menggunakan hak pakai untuk mendirikan bangunan atau membuka suatu usaha. Metode yang digunakan adalah metode penelitian hukum normatif empiris yaitu penggabungan dari ketentuan hukum normatif (undang-undang) dengan unsur-unsur empiris (peristiwa hukum di masyarakat/unsur sosial).
\end{abstract}

Kata Kunci: Kepemilikan, Hak Atas Tanah, Orang Asing. 


\section{A. PENDAHULUAN}

Tanah adalah sebagai karunia Tuhan Yang Maha Esa kepada bangsa Indonesia, merupakan salah satu sumber utama bagi kelangsungan hidup dan penghidupan bangsa. Maka tanah adalah untuk diusahakan atau digunakan bagi pemenuhan kebutuhan yang utama dan nyata. Sehubungan dengan itu penyediaan, peruntukan, penguasaan, penggunaan dan pemeliharaannya perlu diatur agar terjamin kepastian hukum dalam penguasaan dan pemanfaatannya serta sekaligus terselenggara perlindungan hukum bagi rakyat, terutama golongan petani dengan tetap mempertahankan kelestarian kemampuannya dalam mendukung kegiatan pembangunan yang berkelanjutan. ${ }^{1}$

Tanggal $24 \quad$ September 1960 diundangkan Undang-Undang Nomor 5 Tahun 1960 tentang Peraturan Dasar PokokPokok Agraria. Undang-undang ini lebih dikenal dengan Undang-Undang Pokok Agraria (UUPA). UUPA melaksanakan ketentuan pasal 33 ayat (3) Undang-Undang Dasar Negara Republik Indonesia tahun 1945, sebagaimana disebutkan dalam pasal 2 ayat (1) UUPA, yaitu : "Atas dasar ketentuan dalam pasal 33 ayat (3) Undang-Undang Dasar dan hal-hal sebagai yang dimaksud dalam Pasal 1, bumi, air, dan kekayaan alam yang terkandung di dalamnya itu pada tingkatan tertinggi dikuasai oleh negara, sebagai organisasi kekuasaan seluruh rakyat. Berdasarkan rumusan Pasal 1 ayat (2) dapat ditarik hal penting, yaitu bumi, air dan kekayaan yang terkandung di dalamnya, dimiliki secara kolektif oleh bangsa Indonesia dan memiliki sifat komunalistik religius. ${ }^{2}$ Hak atas tanah adalah hak yang memberi wewenang kepada pemegang haknya untuk menggunakan dan/atau mengambil manfaat

\footnotetext{
1 Boedi Harsono, Menuju Penyempurnaan Hukum Tanah Nasional, cet. 3 , Jakarta : Universitas Trisakti, 2017, hal.3.

2 Martin Roestamy, Konsep-Konsep Hukum Kepemilikan Properti Bagi Asing Dihubungkan dengan Hukum Pertanahan, Bandung: Alumni, 2011, hlm. 52
}

dari tanah yang dihakinya. ${ }^{3}$ Hak-hak atas tanah bukan hanya memberikan wewenang mempergunakan sebagian tertentu permukaan bumi yang bersangkutan, yang disebut "tanah", tetapi juga tubuh bumi yang ada di bawahnya dan air serta ruang yang ada di atasnya. ${ }^{4}$

Hak milik merupakan induk dari hak guna bangunan, hak sewa bangunan, dan juga hak pakai. ${ }^{5}$ Dimana hak milik tersebut hanya berlaku bagi warga Negara Indonesia (WNI) sedangkan orang asing tidak diperbolehkan menguasai tanah sebagai hak milik sebagaimana dalam UUPA Nomor 5 tahun 1960 pasal 26 ayat (2) dimana apabila orang asing mendapat hak milik maka tanah tersebut dikuasai oleh Negara. Selain itu terdapat pembatasan pemilikan hak atas tanah bagi warga Negara asing dan badan hukum asing menurut Hukum Tanah Nasional dalam Undang- Undang Pokok Agraria pasal 21 ayat (3), pasal 26 ayat (2), pasal 30 ayat (2), pasal 36 ayat (2) dan pasal 42 UUPA jo. Pasal 39 PP No. 40/1996.

Hal ini untuk mengurangi adanya hak kepemilikan atas tanah bagi orang asing. Karena selain menjaga agar tanah WNI tidak dikuasai oleh WNA juga membantu WNI agar dapat memanfaatkan tanah hak miliknya untuk menujang kehidupannya. ${ }^{6}$ Sekalipun UUPA melarang orang asing mempunyai hak milik atas tanah namun UUPA tidak menutup kesempatan warga Negara asing dan badan hukum asing untuk mempunyai hak atas tanah dengan beberapa batasan dan pengecualian. Sehingga semakin jelas kepentingan warga negara Indonesia di atas segala-galanya. Dari paparan di atas maka rumusan masalah

\footnotetext{
3 Urip Santoso, Perolehan Hak Atas Tanah. Jakarta : Kencana Prenadamedia ,2015, hlm.21.

${ }^{4}$ Boedi Harsono, Hukum Agraria Indonesia Sejarah Pembentukan Undang-Undang Pokok Agrarian, Isi dan Pelaksanaannya, Jakarta: Djambatan, 2008, jilid 1, hlm.8

${ }^{5}$ Kadek Rita, Ni Made, Jurnal Kertha Negara : Hak Atas Tanah Bagi Orang Asing di Indonesia Terkait dengan Undang-Undang Nomor 5 Tahun 1960, hlm.2.

${ }^{6}$ Urip Santoso, Op. cit, hlm. 25
} 
adalah: Apa yang termasuk klasifikasi hak atas tanah? Bagaimana kepemilikan hak-hak atas tanah bagi warga negara asing?

\section{B. METODE PENELITIAN}

Penelitian ini merupakan penelitian hukum normatif empiris, penelitian yang memperhatikan bahwa hukum bekerja pada segi kaidah/norma yaitu perundang-undangan yang berkaitan dengan hak atas tanah yang tidak terlepas dari unsur sosial/empiris yakni kenyataan adanya pemilikan hak atas tanah bagi warga Negara asing. Pendekatan dalam penelitian ini, mengenai berlakunya hukum positif. 7 Yaitu berlakunya perundangundangan hak atas atas tanah yang relevan dengan permasalahan kepemilikan hak atas tanah bagi warga Negara asing.

\section{KERANGKA KONSEPTUAL}

Metode yang digunakan adalah Metode Penelitian Normatif Empiris yaitu penggabungan dari ketentuan hukum normatif (undang-undang) dengan unsur-unsur empiris (peristiwa hukum di masyarakat/unsur sosial). Adapun pendekatan dalam penelitian yaitu berlakunya hukum positif. ${ }^{8}$ Dalam hal ini perundang-undangan hak atas tanah yang saat ini digunakan dengan permasalahan kepemilikan hak atas bagi warga negara asing yang ada di Indonesia dengan cara melakukan analisis terhadap data hukum dan hasil yang diperoleh dalam penelitian dengan cara mengetahui makna yang dikandung oleh istilah yang digunakan dalam peraturan perundang-undangan, sekaligus mengetahui masalah yang terjadi dalam penerapan/pelaksana dalam hak atas tanah bagi warga asing. ${ }^{9}$

Teknik dalam pengumpulan data dengan cara studi pustaka yaitu teknik pengumpulan dan informasi dengan menelaah

\footnotetext{
7 Soerjono Soekanto. Pengantar penelitian hukum, Jakarta : UI Press, 1999, hlm. 80.

8 Rokilah,Jurnal Ajudikasi : Implikasi Kewarganegaraan Ganda bagi Warga Negara Indonesia, Vol.1, No.2 (Desember 2017), hlm.56. ${ }^{9}$ Ibid
}

sumber-sumber tertulis yang relevan dan berhubungan dengan objek yang sedang diteliti sehingga mampu menjawab permasalahan yang dihadapi ${ }^{10}$. Analisis data dilakukan secara kualitatif yaitu dengan menelaah seluruh data yang tersedia kemudian dilakukan reduksi data sehingga menghasilkan penafsiran data yang sesuai dengan tujuan penelitian.

Hak atas tanah adalah hak yang memberi wewenang kepada pemegang haknya untuk menggunakan tanah dan/atau mengambil manfaat dari tanah yang dihakinya. Perkataan "menggunakan" mengandung pengertian bahwa hak atas tanah itu digunakan untuk kepentingan bangunan (non-pertanian), sedangkan perkataan "mengambil manfaat" mengandung pengertian bahwa hak atas tanah itu digunakan untuk kepentingan bukan mendirikan bangunan, misalnya untuk kepentingan pertanian, perikanan, peternakan, dan perkebunan. ${ }^{11}$

Hak atas tanah terdiri dari berbagai macam hak tersebut dapat diperoleh berdasarkan transaksi, perbuatan hukum atau ketentuan perundang-undangan yang mengaturnya, secara garis besar hanya ada dua $:^{12}$

1. Hak yang dikuasai perseorangan atau badan hukum

2. Hak yang dikuasai oleh negara Bagi orang asing berlaku larangan kepemilikan atas tanah hak milik sesuai Pasal 21 UUPA, serta bagi badan-badan hukum yang ingin berkedudukan di Indonesia harus memenuhi syarat-syarat yang ditentukan oleh pemerintah. Hal ini sebagai upaya agar tanah yang ada di Indonesia tidak dimiliki oleh warga negara asing karena itu merupakan hak mutlak bagi warga negara Indonesia. ${ }^{13}$ Selain

\footnotetext{
${ }^{10}$ Ibid

${ }^{11}$ Urip Santoso, Hukum Agraria Kajian Komprehesif, Jakarta: Kencana Prenadamedia, 2012, hlm.84.

12 Jimmly Joses Sembiring, Panduan Mengurus Sertifikat Tanah, cet. 1, Jakarta: Visimediia, 2010, hlm. 6

${ }^{13}$ Urip Santoso, Op. Cit, hlm. 17
} 
itu berlaku pula asas nasionalitas bahwa hanya memberikan hak kepada warga negara Indonesia dalam hal pemilikan atas tanah yang mana telah menutup kemungkinan bagi warga negara asing untuk memilikinya.Penerapan asas nasionalitas dalam UUPA terutama dalam hal kepemilikan atas tanah memberikan konsekuensi adanya perbedaan perlakuan antara warga negara Indonesia dengan warga negara asing. 14 Perbedaan perlakuan tersebut dianggap wajar terutama terkait dengan kedudukan tanah bagi masyarakat Indonesia yang memiliki kedudukan yang penting.

Namun dalam asas nasionalitas tidak sepenuhnya melarang untuk memiliki hak atas tanah misalnya, dalam hal yang sangat terbatas orang-orang asing diperbolehkan menguasai dan menggunakan tanah dengan Hak Milik, Hak Guna Usaha, dan Hak Guna Bangunan dengan jangka waktu 1 tahun, yaitu bila orang-orang warga Negara Indonesia yang berganti kewarganegaraan dan orangorang asing yang memperoleh warisan dengan pewarisan menurut Undang-Undang $(A b$ Intestato) yaitu pewarisan berdasarkan kedudukan sendiri (uit eigenhoofde). Ahli waris menurut Undang-Undang adalah ahli waris karena kedudukannya sendiri demi hukum berhak mewarisi harta peninggalan pewaris, menurut KUHPerdata, bahwa ahli waris menurut Undang-Undang harus memiliki hubungan darah dengan pewaris, dan terdapat pengecualian-pengecualian tertentu bagi warga negara asing untuk mendapatkan suatu hak atas tanah di Indonesia selain hak milik. ${ }^{15}$

$$
\text { Dalam Undang-Undang Nomor } 12
$$

tahun 2006 Pasal 2 Tentang
kewarganegaraan, bahwa yang menjadi warga negara Indonesia adalah orang-orang bangsa

\footnotetext{
${ }^{14}$ Michael Wisnoe, Tesis : Kepemilikan Hak Atas Tanah bagi Warga Negara Asing dan Kewargangaraan Ganda, Depok : Fakultas Hukum Universitas Indonesia, 2012, hlm. 17

15 Adhe Mallombang, Blog advokasi 03 : Proses Pewarisan Melalui Ab Intestato dan Testamento (Testamen). 09 desember 2011 (08 November 2018, 06.30)
}

Indonesia asli dan orang-orang bangsa lain yang disahkan dengan Undang-Undang sebagai warga negara. Dalam status seorang warga negara Indonesia terdapat hak dan kewajiban yang harus dipenuhi yang tercantum dalam pasal 27 sampai 34 UUD 1945. Sedangkan pengertian Warga Negara Asing terdapat dalam Pasal 1 angka 17 Undang-Undang Nomor 20 Tahun 2009 Tentang Gelar, Tanda Jasa dan Tanda Kehormatan yaitu, " Orang-orang bangsa lain yang disahkan dengan Undang-Undang sebagai Warga Negara Asing. Menurut penjelasan Undang-Undang kewarganegaraan, Warga Negara Asing adalah "Orang/Badan Hukum Asing yang berstatus Kewarganegaraan Asing dan tidak pernah mengajukan permohonan sehingga ia tidak pernah ditetapkan menjadi Warga Negara Indonesia dan/atau Badan Hukum Indonesia, serta tidak disebabkan karena kehilangan Kewarganegaraan Indonesia menurut ketentuan Undang-Undang Kewarganegaraan di Indonesia". ${ }^{16}$ Pasal 7 Undang-Undang Kewarganegaraan menyebutkan bahwa "Setiap orang yang bukan Warga Negara Indonesia diperlakukan sebagai orang asing".

\section{Berdasarkan}

Undang-Undang

Kewarganegaraan syarat bagi warga negara asing agar dapat menjadi warga negara Indonesia tertera dalam Pasal 8 UndangUndang Kewarganegaraan yang menyebutkan bahwa "Kewarganegaraan Republik Indonesia dapat juga diperoleh melalui pewarganegaraan". Pewarganegaraan adalah cara warga negara asing untuk memperoleh status WNI yang diperoleh melalui permohonan, pewarganegaraan juga sering disebut dengan naturalisasi. Menurut Gatot Supramono ada tiga cara warga negara asing memperoleh status WNI, yaitu dengan

\footnotetext{
16 Mangiliwati Winardi, jurnal Repertorium: Penguasaan Tanah oleh Warga Negara Asing dengan Perjanjian Pinjam Nama (Nominee) di Wilayah Indonesia Menurut Undang-Undang Nomor 5 Tahun 1960, Vol.IV, No. 1 (Januari-Juni 2017)
} 
naturalisasi, perkawinan, dan dengan pemberian oleh Pemerintah RI. ${ }^{17}$

\section{PEMBAHASAN}

\section{Klasifikasi Hak Atas Tanah}

Macam-macam hak atas tanah dimuat dalam pasal 16 UUPA, pasal 53 UUPA, dan dalam Peraturan Pemerintah No. 40 Tahun 1996 tentang Hak Guna Usaha, Hak Pakai Atas Tanah, LNRI Tahun 1996 No. 58- TLNRI No. 3643. Dalam pasal 16 ayat (1) UUPA menetapkan macam hak atas tanah yaitu: ${ }^{18}$
a. Hak Milik
b. Hak Guna Usaha
c. Hak Guna Bangunan
d. Hak Pakai
e. Hak Sewa Untuk Bangunan
f. Hak Membuka Tanah
g. Hak Memungut Hasil Hutan

Macam hak atas tanah yang bersifat sementara ditetapkan dalam pasal 53 ayat (1) UUPA, yaitu : ${ }^{19}$

a. Hak Gadai (Gadai Tanah)

b. Hak Usaha Bagi Hasil (Perjanjian Bagi Hasil)

c. Hak Menumpang

d. Hak Sewa Tanah Pertanian

Pada hak atas tanah yang bersifat tetap di atas, sebenarnya Hak Membuka Tanah dan Hak Memungut Hasil Hutan bukanlah hak atas tanah dikarenakan keduanya tidak memberikan wewenang kepada pemegang haknya untuk menggunakan tanah atau mengambil manfaat dari tanah yang dihakinya. Namun, sekedar menyesuaikan dengan sistem Hukum Adat, maka kedua hak tersebut dicantumkan juga ke dalam hak atas tanah yang bersifat tetap. Kemudian dalam Pasal 16 jo. Pasal 53 UUPA tidak bersifat limitatif, artinya di samping hakhak atas tanah yang telah disebutkan dalam UUPA, kelak dimungkinkan

\footnotetext{
${ }^{17} \mathrm{Ibid}$, hlm. 66

${ }^{18}$ Urip Santoso, Op. cit, hlm. 24

${ }^{19}$ Ibid
}

lahirnya hak atas tanah baru yang diatur secara khusus dengan Undang-Undang. ${ }^{20}$ Dalam Pasal 53 UUPA tercantum beberapa hak yang bersifat sementara yang dapat digunakan oleh orangperorang atau badan hukum seperti hak gadai, hak usaha bagi hasil, hak menumpang, dan hak sewa pertanian. ${ }^{21} \mathrm{Di}$ bagian ini penulis hanya akan memaparkan hak-hak atas tanah yang dinilai berhubungan langsung dengan kepemilikan hak atas tanah bagi warga Negara asing yaitu, Hak Milik, Hak Guna Usaha, Hak Guna Banguan, dan Hak Pakai.

\section{Hak Milik}

Hak Milik adalah hak turuntemurun, terkuat dan terpenuh yang dapat dipunyai orang atas tanah, dengan mengingat ketentuan pasal 6 (pasal 20 ayat (1) UUPA). Kemudian dalam pasal 21 disebutkan yang dapat mempunyai Hak Milik, yaitu: ${ }^{22}$

1) Hanya warganegara Indonesia dapat mempunyai hak milik.

2) Oleh Pemerintah ditetapkan badan-badan hukum yang dapat mempunyai hak milik dan syarat-syaratnya.

3) Orang asing yang sesudah berlakunya Undang-undang ini memperoleh hak milik karena pewarisan tanpa wasiat atau percampuran harta karena perkawinan, demikian pula warganegara Indonesia yang mempunyai hak milik dan setelah berlakunya undangundang ini kehilangan kewarganegaraannya wajib melepaskan hak itu dalam jangka waktu satu tahun sejak diperolehnya hak tersebut atau

\footnotetext{
${ }^{20} \mathrm{Ibid}$, hlm. 90

${ }^{21}$ Ida Bagus, Wyasa Putra, Hukum Bisnis Pariwisata, Bandung : Refika Aditama, 2003, hlm. 85.

${ }^{22}$ Ibid, hlm. 38
} 
hilangnya kewarganegaraan itu. Jika sesudah jangka waktu tersebut lampau hak milik itu tidak dilepaskan, maka hak tersebut hapus karena hukum dan tanahnya jatuh pada negara, dengan ketentuan bahwa hak-hak pihak lain yang membebaninya tetap berlangsung.

4) Selama seseorang di samping kewarganegaraan Indonesianya mempunyai kewarganegaraan asing maka ia tidak dapat mempunyai tanah dengan hak milik dan baginya berlaku ketentuan dalam ayat 3 pasal ini.

Dalam macam-macam hak atas tanah di atas Hak Milik merupakan hak yang paling kuat atas tanah, yang memberikan kewenangan kepada pemiliknya untuk memeberikan kembali suatu hak lain di atas bidang tanah yang mejadi Hak Milik baginya (dapat berupa Hak Guna Bangunan atau Hak Pakai, dengan pengecualian Hak Guna Usaha). Dapat juga diketahui bahwa pada dasarnya Hak Milik atas tanah hanya boleh dimiliki oleh warga Negara Indonesia saja, itu berarti Hak Milik tersebut tidak dapat dimiliki oleh warga Negara asing dan badan hukum, baik yang didirikan di Indonesia maupun didirikan di luar negeri dengan pengecualian badanbadan hukum tertentu yang diatur dalam Peraturan Pemerintah No. 38 Tahun 1963, yaitu: ${ }^{23}$

a. Bank-bank yang didirikan oleh Negara (selanjutnya disebut Bank Negara);

b. Perkumpulan-perkumpulan

Koperasi Pertanian yang didirikan berdasar atas Undang-undang No. 79 tahun
1958 (Lembaran-Negara tahun 1958 No. 139);

c. Badan-badan keagamaan, yang ditunjuk oleh Menteri Pertanian/Agraria, setelah mendengar Menteri Agama;

d. Badan-badan sosial, yang ditunjuk oleh Menteri Pertanian/Agraria, setelah mendengar Menteri Kesejahteraan Sosial

Maksud dari Hak Milik merupakan hak terkuat atau terpenuh tidak berarti bahwa hak tersebut merupakan hak mutlak dan tidak dapat diganggugugat. ${ }^{24}$ Terkuat disitu bermaksud untuk membedakan dengan hak guna usah, hak guna bangunan, dan hak pakai juga hak-hak lainnya. Agar menunjukkan hak miliklah yang mempunyai kekuatan hukum paling kuat dan penuh diantara hak-hak atas tanah lain yang dapat dimiliki seseorang atau suatu badan hukum tertentu.

Selain itu pengecualian bagi orang asing dalam Hak Milik juga berlaku bagi pewarisan tanpawasiat atau percampuran harta karena perkawinankewarganegaraan ganda (bipatride) yang disebutkan dalam pasal 21 ayat (3) dan (4) UUPA wajib melepaskan hak miliknya dalam jangka waktu satu tahun sejak diperolehnya hak tersebut atau hilangnya kewarganegaraan itu. ${ }^{25}$ Dengan demikian, hak tersebut hapus karena hukum dan tanahnya jatuh pada Negara, dengan ketentuan bahwa hak-hak pihak lain yang membebaninya tetap berlangsung.

Negara sebagai penguasa atas tanah yang ada diseluruh wilyah republik Indonesia mempunyai kewenangan untuk memberikan, sekaligus mencabut hak milik yang

${ }^{23}$ Michael Wisnoe, Op. cit, hlm. 20

${ }^{24}$ Ibid, hlm. 21

${ }^{25} \mathrm{Ibid}$ 
telah diberikan kepada warga negaranya. Hak milik tersebut dapat dicabut jika ada kepentingan umum misalnya pembangunan tol atau pelebaran jalan.Pencabutan hak milik oleh Negara tentunya tidak dapat dilakukan dengan begitu saja tanpa memberikan kompensasi atau ganti kerugian kepada pemegang hak milik atas tanah. Hal ini dijelaskan dalam pasal 27 UUPA, sebab tanah jatuh kepada Negara $:^{26}$

1. Karena pencabutan hak berdasarkan pasal 18, yaitu untuk kepentingan umum, termaksud kepentingan banngsa dan Negara serta kepentingan bersama dari rakyat, hak-hak atas tanah dapat cabut, dengan memberikan ganti kerugian yang layak dan menurut cara yang diatur dengan undangundang

2. Karena penyerahan dengan sukarela oleh pemiliknya

3. Karena ditelantarkan

4. Karena ketentuan Pasal 21 ayat (3) yang menyebutkan bahwa orang asing atau warga yang memiliki kewarganegaraan lain selain Indonesia memiliki jangka waktu satu tahun dalam hak milik atas tanah.

5. Dan ketentuan dalam pasal 26 ayat (2) yang menyebutkan setiap jual beli, penukaran, penghibahan, pemeberian dengan wasiat dan perbuatanperbuatan lain yang dimaksudkan untuk langsung atau tidak langsung memindahkan hak milik kepada orang asing, kepada seorang warga Negara yang di samping kewarganegaraan

${ }^{26}$ Ibid
Indonesianya mempunyai kewarganegaraan asing atau badan kepada suatu badan hukum, kecuali yang ditetapkan oleh pemerintah termaksud dalam pasal 21 ayat (2), adalah batal karena hukum dan tanahnya jatuh kepada Negara, dengan ketentuan, bahwa hak-hak pihak lain yang membebaninya tetap berlangsung serta semua pembayaran yang telah diterima oleh pemilik tidak dapat dituntut kembali.

\section{Hak Guna Usaha}

Perbedaan utama antara Hak Milik dan Hak Guna Usaha adalah kepemilikan atas tanah pada hak guna usah bersifat sementara sedangkan pada hak milik bersifat permanen. ${ }^{27}$ Ketentuan mengenai Hak Guna Usaha diatur dalam pasal 28 UUPA, yaitu:

(1) Hak Guna Usaha adalah hak untuk mengusahakan tanah yang dikuasai langsung oleh Negara dalam jangka waktu sebagaimana tersebut dalam pasal 29, guna perusahaan, pertanian, perikanan atau peternakan.

(2) Hak Guna Usaha diberikan atas tanah yang luasnya paling sedikit 5 memakai investasi modal yang layak dan hektar, dengan ketentuan bahwa jika luasnya 25 hektar atau lebih harus teknik perusahaan yang baik, sesuai perkembangan zaman.

(3) Hak Guna Usaha dapat beralih dan dialihkan kepada pihak lain

Hak Guna Usaha adalah hak khusus yang diadakan untuk kepentingan ekonomi seperti untuk pertanian, perikanan dan peternakan. ${ }^{28}$ Hak Guna Usaha tidak dapat diberikan 
kepada warga Negara asing, hanya mungkin bagi badan-badan hukum yang bermodal asing dengan pembatasan yang disebutkan dalam pasal 55 UUPA " berlaku untuk sementara selama sisa waktu hak-hak tersebut dengan jangka waktu paling lama 20 tahun".

Karena Hak Guna Usaha diberikan untuk kepentingan ekonomi maka sudah sepantasnya memiliki jangka waktu yang dijelaskan dalam pasal 29 UUPA, yaitu: ${ }^{29}$

(1) Hak Guna Usaha diberikan untuk waktu paling lama 25 tahun

(2) Untuk perusahaan yang memerlukan waktu yang lebih lama dapat diberikan hak guna usaha-usaha untuk waktu paling lama 35 tahun

(3) Atas permintaan pemegang hak dan mengingat keadaan perusahaannya jangka waktu yang dimaksud dalam ayat (1) dan (2) pasal ini dapat diperpanjang dengan waktu paling lama 25 tahun.

Hak Guna Usaha dapat diberikan hanya kepada "Warga Negara Indonesia dan Badan hukum yang didirikan menurut hukum Indonesia dan berekedudukan di Indonesia" (pasal 30 ayat 1). Jika orang atau badan hukum yang disebutkan dalam pasal 30 ayat (1) tersebut tidak lagi memenuhi syarat-syarat maka dalam jangka 1 tahun wajib melepaskan atau mengalihkan hak tersebut kepada pihak lain yang dinilai memenuhi syarat. Apabila setelah waktu ditentukan hak tersebut tidak dilepaskan atau dialihkan, hak itu hapus demi hukum, dengan ketentuan bahwa hak-hak pihak lain akan diabaikan menurut ketentuan-

\footnotetext{
${ }^{29} \mathrm{Ibid}$, hlm. 26
}

ketentuan yang ditetapkan oleh Peraturan Pemerintah. ${ }^{30}$

Hak Guna Usaha tidak dapat dimiliki oleh warga Negara asing, badan hukum yang dapat mempunyai hak itu hanyalah badan hukum yang bermodal nasional yang progresif baik asli maupun tidak asli.Bagi badanbadan hukum yang bermodal asing, hak guna usaha hanya memungkinkan untuk diberikan jika hal itu diperlukan oleh undang-undang yang mengatur pembangunan nasional berencana. ${ }^{31}$

\section{Hak Guna Bangunan} berbunyi : ${ }^{32}$

Dalam pasal 35 UUPA yang

(1) Hak Guna Bangunan adalah hak untuk mendirikan dan mempunyai bangunan-bangunan atas tanah yang bukan miliknya sendiri, dengan jangka waktu paling lama 30 tahun.

(2) Atas permintaan pemegang hak dan dengan mengingat keperluan serta keadaan bangunanbangunannya, jangka waktu tersebut dalam ayat (1) dapat diperpanjang dengan waktu paling lama 20 tahun.

(3) Hak Guna Bangunan dapat beralih dan dialihkan kepada pihak lain.

Ini berarti seorang pemegang hak guna bangunan adalah berbeda dari pemegang hak milik atas bidang tanah di mana bangunan tersebut didirikan atau bisa juga diartikan, pemegang hak guna bangunan bukanlah pemegang hak milik dari tanah di mana bangunan tersebut didirikan. Dalam Peraturan Pemerintah No. 40 Tahun 1996 pasal 21 disebutkan bahwa tanah yang dapt
${ }^{30}$ Ibid
${ }^{31} \mathrm{Ibid}$, hlm. 27
${ }^{32} \mathrm{Ibid}$, hlm. 29 
diberikan Hak Guna Bangunan adalah : $:^{33}$
a. Tanah Negara
b. Tanah Pengelola
c. Tanah Hak Milik

Hak Guna Bangunan yang diberikan di atas tanah Negara dan tanah pengelola atau tanah Hak Pengelolaan diatur dalam pasal 22 PP No. 40 Tahun 1996, yaitu: ${ }^{34}$

(1) Hak Guna Bangunan atas tanah Negara diberikan dengan keputusan pemberian hak oleh menteri atau pejabat yang ditunjuk

(2) Hak Guna Bangunan atas tanah Hak Pengelolaan diberikan dengan keputusan pemberian hak oleh menteri atau pejabat yang ditunjuk berdasarkan usul pemegang hak pengelolaan

(3) Ketentuan mengenai tata cara dan syarat permohonan dan pemberian Hak Guna Usaha atas tanah Negara dan atas tanah Hak Pengelolaan diatur lebih lanjut dengan Keputusan Presiden.

Sedangkan ketentuan Hak Guna Bangunan yang diberikan di atas tanah hak milik diatur dalam pasal 24 Peraturan Pemerintah No. 40 Tahun 1996, sebagai berikut : ${ }^{35}$

(1) Hak Guna Bangunan atas tanah Hak Milik terjadi dengan pemberian oleh pemegang Hak Milik dengan akta yang dibuat oleh Pejabat Pembuat Akta Tanah.

(2) Pemberian Hak Guna Banguan atas tanah Hak Milik sebagaimana yang dimaksud dalam ayat (1) wajib didaftarkan pada Kantor Pertanahan.

(3) Hak Guna Banguan atas tanah Hak Milik mengikat pihak ketiga sejak didaftarkan sebagaimana yang dimaksud dalam ayat (2).

(4) Ketentuan mengenai tata cara pemberian dan pendaftaran Hak Guna Banguan atas tanah Hak Milik diatur lebih lanjut dengan Keputusan Presiden.

Selanjutnya dalam ketentuan penggunaan Hak Guna Bangunan baik di atas tanah Negara, tanah Hak Pengelolaan maupun tanah Hak Milik terdapat jangka waktu yang telah ditentukan.Namun terdapat perbedaan dalam ketentuan jangka waktu yang diberikan antara Hak Guna Bangunan baik di atas tanah Negara, tanah Hak Pengelolaan maupun tanah Hak Milik. Dalam Pasal 25 PP Nomor 40 Tahun 1996 disebutkan ketentuan jangka waktu yang berlaku bagi pemberian Hak Guna Bangunan atas tanah Negara, dan tanah Hak Pengelolaan, yaitu : ${ }^{36}$

(1) Hak Guna Bangunan sebagaimana yang dimaksud dalam pasal 22 diberikan jangka waktu paling lama tiga puluh tahun dan dapat diperpanjang untuk jangka waktu paling lama dua puluh tahun

(2) Sesudah jangka waktu Hak Guna Bangunan dan perpanjangannya sebagaimana yang dimaksud dalam ayat (1) berakhir, kepada bekas pemegang hak dapat diberikan pembaruan Hak Guna Bangunan di atas tanah yang sama.

Untuk ketentuan jangka waktu bagi pemberian Hak Guna Bangunan atas tanah Hak Milik diatur dalam Peraturan Pemerintah Nomor 40 Tahun 1996 pasal $29:^{37}$

(1) Hak Guna Bangunan atas tanah Hak Milik diberikan untuk

\footnotetext{
${ }^{33}$ Ibid

${ }^{34}$ Ibid, hlm. 30

${ }^{35}$ Ibid
}

${ }^{36}$ Ibid

${ }^{37}$ Ibid, hlm. 31 
jangka waktu paling lama tiga puluh tahun.

(2) Atas kesepakatan antara pemegang Hak Guna Bangunan dengan pemegang Hak Milik,Hak Guna Bangunan atas tanah Hak Milik dapat diperbarui dengan pemberian Hak Guna Bangunan baru dengan akta yang dibuat oleh Pejabat Pembuat Akta Tanah dan hak tersebut wajib didaftarkan.

Subjek hukum yang dapat menjadi pemegang Hak Guna Bangunan disebutkan dalam pasal 36 Undang-Undang Pokok Agraria (UUPA) : $:^{38}$

(1) Yang dapat mempunyai Hak Guna Bangunan ialah :

a. Warga Negara Indonesia

b. Badan hukum yang didirikan menurut hukum Indonesia dan berkedudukan di Indonesia

(2) Orang atau badan hukum yang mempunyai hak guna bangunan dan tidak lagi memenuhi syaratsyarat yang tersebut dalam ayat 1 pasal ini dalam jangka waktu 1 tahun wajib melepaskan atau mengalihkan hak itu kepada pihak lain yang memenuhi syarat. Ketentuan ini berlaku juga terhadap pika yang memperoleh hak guna bangunan, jika ia tidak memenuhi syarat tersebut. Jika hak guna bangunan yang bersangkutan tidak dilepaskan atau dialihkan dalam jangka waktu tersebut, maka hak itu hapus karena hukum, dengan ketentua, bahwa hak-hak pihak lain akan diindahkan menurut ketentuan-ketentuan

yang ditetapkan dengan Peraturan Pemerintah.

\section{Hak Pakai}

Hak pakai adalah hak untuk menggunakan dan/atau memungut hasil dari tanah yang dikusai langsung oleh Negara atau tanah milik orang lain, yang memberi wewenang dan kewajiban yang ditentukan dalam keputusan pemberiannya oleh pejabat yang berwenang memberikannya atau dalam perjanjian dengan pemilik tanahnya, yang bukan perjanjian sewa-menyewa atau perjanjian pengelolaan tanah, segala sesuatu asal tidak bertentangan dengan jiwa dan ketentuan-ketentuan undangundang ini ${ }^{39}$. Subjek hukum yang dapat menggunakan, mempunyai atau pemegang hak pakai terdapat dalam 42 UUPA, sebagai berikut :

a. Warga Negara Indonesia

b. Orang asing yang berkedudukan di Indonesia

c. Badan hukum yang didirikan menurut hukum Indonesia dan berkedudukan di Indonesia

d. Badan hukum asing yang mempunyai perwakilan di Indonesia

Subyek hukum hak pakai kemudian diperjelas dengan uraian yang lebih lengkap dalam pasal 39 Peraturan Pemerintah Nomor 40 Tahun 1996. Yang memiliki hak pakai ialah : ${ }^{40}$

a. Warga Negara Indonesia

b. Badan hukum yang didirikan menurut hukum Indonesia dan berkedudukan di Indonesia

\footnotetext{
39 Suparman Usman, Hukum Agraria di Indonesia,Serang : UIN "SUHADA" Press. 2014 hlm. 415

${ }^{40}$ Michael Wisnoe, Op. Cit, hlm. 35
} 
c. Departemen, lembaga pemerintah non departemen, dan pemerintah daerah

d. Badan-badan keagamaan dan social

e. Orang asing yang berkedudukan di Indonesia

f. Badan hukum asing yang mempunyai perwakilan di Indonesia

g. Perwakilan Negara asing dan perwakilan badan internasional

Dengan beberapa ketentuan yang dijelaskan dalam pasal 40 Peraturan Pemerintah Nomor 40 Tahun 1996, yaitu: ${ }^{41}$

(1) Pemegang Hak Pakai yang tidak lagi memenuhi syarat sebagaimana yang dimaksud dalam pasal 39 dalam waktu satu tahun wajib melepaskan atau mengalihkan hak pakai itu pada pihak lain yang memenuhi syarat

(2) Apabila dalam jangka waktu sebagaimana dimaksud dalam ayat (1) haknya tidak dilepaskan atau dialihkan, hak tersebut hapus karena hukum dengan ketentuan hak-hak pihak lain yang terkait di atas tanah tersebut tetap diperhatikan.

Dalam pasal 41 ayat (2), hak pakai dapat dberikan dalam hal: ${ }^{42}$

a. Selama jangka waktu yang tertentu atau selama tanahnya dipergunakan untuk keperluan yang tertentu.

b. Dengan Cuma-Cuma, dengan pembayaran atau pemberian jasa berupa apapun.

Kita juga dapat mengetahui bahwa jangka waktu pemberian hak pakai berbeda-beda dengan bebrapa ketentuan: ${ }^{43}$

1. Hak pakai yang diberikan di atas tanah negara, dapat diberikan untuk waktu yang tidak terbatas, jika pemegang hak pakai adalah:

a. Departemen

b. Lembaga pemerintah non departemen dan Pemerintah daerah

c. Perwakilan negara asing dan perwakilan lembaga internsional

d. Badan keagamaan dan badan social

Namun jika pemegang hak pakainya adalah:

a. Warga Negara Indonesia

b. Badan hukum yang didirikan menurut hukum Indonesia yang berkedudukan di Indonesia

c. Orang asing yang berkedudukan di Indonesia

d. Badan hukum asing yang mempunyai perwakilan di Indonesia

Jangka waktu yang diberikan paling lama 45 (empat puluh lima) tahun yang terdiri 25 (dua puluh lima) tahun untuk pertama kali dan 20 (dua puluh) tahun untuk perpanjangannya.

2. Hak pakai yang diberikan di atas tanah dengan hak pengelolaan berlaku ketentuan yang telah disebutkan untuk hak pakai yang diberikan di atas tanah negara, dengan ketentuan bahwa, hak pakai atas tanah hak pengelolaan dapat

${ }^{41}$ Ibid

${ }^{42}$ Ibid, hlm. 36

${ }^{43}$ Ibid 
diperpanjang atau diperbaharui atas usul pemegang hak pengelolaan.

3. Hak pakai yang diberikan di atas tanah hak milik, jangka waktu pemberiannya paling lama 25 (dua puluh lima) tahun yang dibuat dihadapan Pejabat Pembuat Akta Tanah (PPAT). Hak pakai yang telah habis dapat diperbaharui bukan diperpanjang.

\section{Kepemilikan Hak-hak Atas Tanah Bagi Asing}

Menurut UUPA, hak milik, hak guna usaha dan hak guna bangunan tidak dapat diberikan kepada orang asing atau badan hukum asing. Bagi warga negara asing dan badan hukum asing yang berkudukan di Indonesia dapat diberikan hak pakai. Sesuai dengan jenisnya badan hukum dibedakan pula antara badan hukum public dan badan hukum privat/keperdataan. Badan hukum yang bersifat public (perwakilan negara asing, perwakilan badanbadan internasional) dan yang bersifat keperdataan. ${ }^{44}$

Namun dalam hal yang sangat khusus orang-orang asing boleh menguasai dan menggunakan tanah dengan hak milik, hak guna usaha dan hak guna bangunan itupun sangat terbatas hanya diperbolehkan selama 1 (satu) tahun yaitu bagi warga negara Indonesia yang berganti kewarganegaraan dan orang-orang asing yang memperolehnya melalui pewarisan Ab Intestato. ${ }^{45}$

44 Maria S.W Sumardjono, Alternatif Kebijakan Pengaturan Hak Atas Tanah Beserta Bangunan Bagi Warga Negara Asing dan Badan Hukum Asing. Jakarta : Kompa, 2008). Hal. 44

${ }^{45}$ Michael Wisnoe, Op. Cit, hlm. 46
Jadi, untuk warga negara asing sama sekali tidak terbuka kemungkinan untuk mendapatkan hak atas tanah dalam system hukum pertanahan, kecuali hak pakai. Demikian pula halnya bagi badan hukum asing. Akan tetapi bagi orang asing dalam hal ini Investor Asing dapat memiliki tanah di Indonesia melalui perusahaan nasional dalam rangka penanaman modal asing (PMA) berdasarkan system hukum di Indonesia. ${ }^{46}$

Untuk tempat tinggal, orang asing dapat menyewa rumah milik orang Indonesia ataupun jika ingin membangun rumah sendiri, dimungkinkan menguasai dan menggunakan tanah yang bersangkutan dengan hak pakai atau hak sewa. Hak sewa untuk bangunan dan hak pakai menurut hukumnya dapat diberikan dengan jangka waktu sampai 25 (dua puluh lima) tahun. ${ }^{47}$

Kebijakan mengenai orangorang dan badan-badan hukum asing di bidang pertanahan, diatur antara lain dalam :

1. Pasal 33 ayat (3) UndangUndang Dasar 1945

2. Undang-Undang No. 5 Tahun 1960 tentang Peraturan Dasar Pokok-Pokok Agraria (UUPA)

3. Undang-Undang No. 25 Tahun 2007 tentang Penanaman Modal Asing

4. Undang-Undang No. 20 tahun 2011 tentang Rumah Susun

5. Keputusan Presiden Tahun 1992

6. Peraturan Pemerintah No. 40 1996 tentang Hak Guna Bangunan, Hak Guna Usaha dan Hak Pakai atas Tanah.

7. Peraturan Pemerintah No. 41 1996 tentangPemilikan Rumah

${ }^{46}$ Ibid, hlm. 47

${ }^{47} \mathrm{Ibid}$ 
Tempat Tinggal atau Hunian oleh Orang Asing yang berkedudukan di Indonesia

8. Keputusan Presiden No. 34 Tahun 1992, tentang pemanfaatan tanah Hak Guna Usaha dan Hak Guna Bangunan untuk Usaha Patungan dalam Rangka Penanaman Modal Asing.

Adapun aspek keadilan dalam peraturan perundang-undangan diatas dapat dilihat dari dua sisi. Pada satu pihak, warga negara asing dan badan hukum asing diberi kesempatan untuk mempunyai hak atas tanah beserta bangunan, namun di pihak lain, agar tidak mengurangi perlindungan yangdiberikan oleh pemerintah kepada warganya sendiri, terutama mereka yang secara ekonomis perlu dibantu, maka diberikan persyaratan bagi warga negara asing dan badan hukum asing untuk mempunyai hak atas tanah beserta bangunan dengan beberapa pembatasan yang telah dijelaskan. ${ }^{48}$

Sesuai dengan ruang lingkup pengaturan, hak atas tanah beserta bangunan, maka instansi yang bertanggung jawab untuk melakukan pengawasan terhadap dipenuhinya persyaratan pemegang hak,dan segala persyaratan terkait dengan hak atas tanahbeserta bangunan yang dapat dimiliki orang asing/ warga negara asing dan badan-badan hukum asing, serta segala bentuk perbuatan hukum yang dapat dilakukan terhadap hak atas tanah beserta bangunan, adalah Instansi yang berwenang di bidang pertanahan, yakni Kepala Kantor Pertanahan sesuai dengan Peraturan Presiden (Perpres) Nomor 10 Tahun

${ }^{48}$ Ibid, hlm. 50
2006 tentang Badan Pertanahan Nasional. ${ }^{49}$

Secara garis besar, Kepala Kantor Pertanahan mencatat pendaftaran dalam rangkaian pemberian hak pakai, termasuk perpanjangan dan pembaharuannya, peralihan, pembebanan, serta hapusnya hak pakai yang bersangkutan. Jika kantor pertanahan dalam melaksanakan tugasnya mengabaikan ketentuan yang berlaku maka dikenakan sanksi administratif sesuai dengan peraturan perundangundangan yang berlaku. ${ }^{50}$

\section{E. KESIMPULAN}

Dalam pasal 16 ayat (1) UUPA menetapkan macam hak atas tanah bersifat tetap terdiri atas Hak Milik, Hak Guna Usaha, Hak Guna Bangunan, Hak Pakai, Hak Sewa Untuk Bangunan, Hak Membuka Tanah, Hak Memungut Hasil Hutan. Sedangkan hak atas tanah bersifat sementara ditetapkan dalam Pasal 53 ayat (1) UUPA yaitu, Hak Gadai, Hak Usaha Bagi Hasil, Hak Menumpang, Hak Sewa Tanah Pertanahan.

Untuk warga negara asing tidak terbuka kemungkinan untuk mendapatkan hak atas tanah dalam hukum sistem hukum pertanahan, kecuali hak pakai. Demikian untuk Badan Hukum Asing, akan tetapi jika warga negara asing dalam hal ini investor asing dapat memiliki tanah di Indonesia melalui perusahaan nasional dalam rangka Penanaman Modal Asing (PMA) berdasarkan system hukum Indonesia. Untuk tempat tinggal, dapat menyewa rumah milik orang Indonesia atau jika ingin membangun rumah sendiri dapat menggunakan tanah dengan Hak Sewa ataupun Hak Pakai. Badan-badan hukum, baik yang bermodal asing sepenuhnya ataupun berupa usaha patungan dengan modal Indonesia, yang

${ }^{49}$ Ibid, hlm. 51

${ }^{50}$ Ibid, hlm. 52 
berbentuk badan hukum Indonesia dimungkinkan menggunakan tanah untuk usahanya dengan Hak Guna Bangunan dan Hak Pakai, sedangkan yang berupa usaha patungan dengan Hak Guna Usaha (Keppres Nomor 34 Tahun 1992).

\section{DAFTAR PUSTAKA}

\section{Buku}

Santoso Urip, Perolehan Hak Atas Tanah. Jakarta : Kencana Prenadamedia ,2015

Santoso Urip, Hukum Agraria kajian komprehesif, .Jakarta : Kencana Prenadamedia, 2012

Sumardjono Maria, Alternatif Kebijakan Pengaturan Hak Atas Tanah Beserta Bangunan Bagi Warga Negara Asing dan Badan Hukum Asing. Jakarta : Kompas, 2008

Suparji, Penanaman Modal Asing di Indonesia, Jakarta: Fakultas Hukum Universitas Al Azhar Indonesia, 2008

Usman Suparman, Hukum Agraria di Indonesia,Serang : UIN "SUHADA" Press. 2014

Bagus Ida, Putra Wyasa, Hukum Bisnis Pariwisata, Bandung : Refika Aditama, 2003

Harsono Boedi, Menuju Penyempurnaan Hukum Tanah Nasional, cet. 3 , Jakarta : Universitas Trisakti, 2017

Harsono Boedi, Hukum Agraria Indonesia Sejarah Pembentukan Undang-Undang Pokok Agrarian, Isi dan Pelaksanaannya, Jakarta: Djambatan, 2008

Roestamy Martin, Konsep-Konsep Hukum Kepemilikan Properti Bagi Asing Dihubungkan dengan Hukum Pertanahan, Bandung: Alumni, 2011

Sembiring Jimmly J, Panduan Mengurus Sertifikat Tanah, cet. 1, Jakarta: Visimediia, 2010

\section{Jurnal}

Wisnoe Michael, Tesis : Kepemilikan Hak Atas Tanah bagi Warga Negara Asing dan Kewargangaraan Ganda, Depok :
Fakultas Hukum Universitas Indonesia, 2012

Winardi Mangiliwati, Jurnal Repertorium: Penguasaan Tanah oleh Warga Negara Asing dengan Perjanjian Pinjam Nama di Wilayah Indonesia Menurut UndangUndang No. 5 Tahun 1960, Surakarta: Fakultas Hukum Universitas Sebelas Maret, 2017.

Rita Kadek, Ni Made, Jurnal Kertha Negara: Hak Atas Tanah Bagi Orang Asing di Indonesia Terkait dengan UndangUndang Nomor 5 Tahun 1960

Sumanto Listyowati, Jurnal Hukum Prioris :Pembatasan Pemilikan Hak Atas Tanah oleh Orang Asing dan Badan Hukum Asing (Studi perbandingan Indonesia-Turki). 2013

Rokilah,Jurnal Ajudikasi : Implikasi Kewarganegaraan Ganda bagi Warga Negara Indonesia, Serang: Universitas Serang Raya. 2017

\section{Peraturan Perundang-undangan}

Undang-Undang Nomor 5 Tahun 1960 Tentang Peraturan Dasar Pokok-Pokok Agraria (UUPA)

Peraturan Pemerintah Republik Indonesia Nomor 38 Tahun 1963 Tentang Penunjukkan Badan-Badan Hukum yang dapat mempunyai Hak Milik Atas Tanah. LN 1963/61; TLN NO. 2555

Peraturan Pemerintah Republik Indonesia Nomor 24 Tahun 1997 Tentang Pendaftaran Tanah. Tambahan Lembar Negara Republik Indonesia Nomor 3696.

Undang-Undang Republik Indonesia Nomor 12 Tahun $2006 \quad$ Tentang Kewarganegaraan Republik Indonesia. Tambahan Lembar Negara Republik Indonesia Nomor 4634

\section{Internet}

Mallombang Adhe, Blog advokasi 03 : Proses Pewarisan Melalui Ab Intestato dan Testamento (Testamen). 09 desember 2011. (08 November 2018, 06.30) 